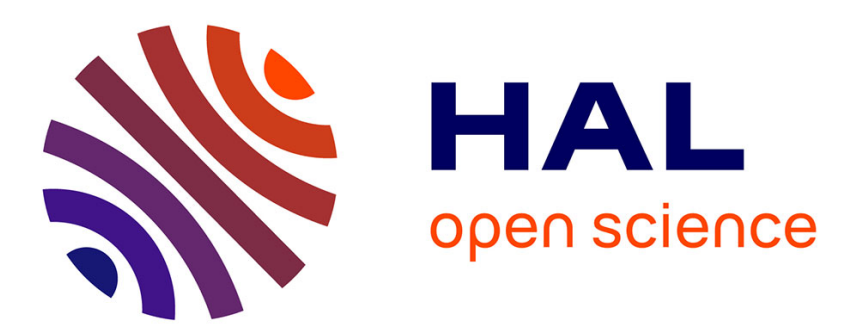

\title{
Biological invasions in agricultural settings: insights from evolutionary biology and population genetics
}

\author{
Thomas T. Guillemaud, Marc Ciosi, Eric Lombaert, Arnaud Estoup
}

\section{To cite this version:}

Thomas T. Guillemaud, Marc Ciosi, Eric Lombaert, Arnaud Estoup. Biological invasions in agricultural settings: insights from evolutionary biology and population genetics. Comptes Rendus Biologies, 2011, 334 (3), pp.237-246. 10.1016/j.crvi.2010.12.008 . hal-02646885

\section{HAL Id: hal-02646885 \\ https://hal.inrae.fr/hal-02646885}

Submitted on 29 May 2020

HAL is a multi-disciplinary open access archive for the deposit and dissemination of scientific research documents, whether they are published or not. The documents may come from teaching and research institutions in France or abroad, or from public or private research centers.
L'archive ouverte pluridisciplinaire $\mathbf{H A L}$, est destinée au dépôt et à la diffusion de documents scientifiques de niveau recherche, publiés ou non, émanant des établissements d'enseignement et de recherche français ou étrangers, des laboratoires publics ou privés. 


\title{
Biological invasions in agricultural settings: Insights from evolutionary biology and population genetics
}

\section{Les invasions biologiques en agriculture : points de vue de la biologie évolutive et de la génétique des populations}

\author{
Thomas Guillemaud ${ }^{\mathrm{a}, *}$, Marc Ciosi ${ }^{\mathrm{a}}$, Éric Lombaert ${ }^{\mathrm{a}}$, Arnaud Estoup ${ }^{\mathrm{b}}$ \\ a Équipe « biologie des populations en interaction », UMR 1301 IBSV INRA-CNRS, université de Nice-Sophia-Antipolis, 400, route des Chappes, 06903 Sophia-Antipolis \\ cedex, France \\ ${ }^{\mathrm{b}}$ INRA UMR centre de biologie et de gestion des populations INRA-IRD-Cirad-Montpellier SupAgro, Campus international de Baillarguet, Montferrier-sur-Lez, France
}

Keywords:

Invasive species

Alien species

Biological control

Bridgehead

Multiple introductions

Diabrotica virgifera virgifera

Harmonia axyridis

\section{Mots clés :}

Espèce envahissante

Espèce exotique

Lutte biologique

Tête de pont

Introductions multiples

Diabrotica virgifera virgifera

Harmonia axyridis

\begin{abstract}
A B S T R A C T
Invasion biology and agriculture are intimately related for several reasons and in particular because many agricultural pest species are recent invaders. In this article we suggest that the reconstruction of invasion routes with population genetics-based methods can address fundamental questions in ecology and practical aspects of the management of biological invasions in agricultural settings. We provide a brief description of the methods used to reconstruct invasion routes and describe their main characteristics. In particular, we focus on a scenario - the bridgehead invasion scenario -, which had been overlooked until recently. We show that this scenario, in which an invasive population is the source of other invasive populations, is evolutionarily parsimonious and may have played a crucial role in shaping the distribution of many recent agricultural pests.

(c) 2011 Académie des sciences. Published by Elsevier Masson SAS. All rights reserved.

R É S U M É

La biologie de l'invasion et l'agriculture sont intimement liées pour plusieurs raisons et en particulier parce que de nombreuses espèces de ravageurs agricoles sont des envahisseurs récents. Nous suggérons que la reconstruction des routes d'invasion par des méthodes de génétique des populations permet d'aborder des questions écologiques fondamentales et des aspects pratiques de la gestion des invasions biologiques en agriculture. Nous fournissons une brève description des méthodes utilisées pour reconstruire les routes d'invasion et décrivons leurs principales caractéristiques. En particulier, nous nous concentrons sur un scénario - le scénario d'invasion "tête de pont " - qui n'avait pas été considéré jusqu'à présent. Nous montrons que ce scénario, dans lequel une population envahissante est la source d'autres populations envahissantes, est parcimonieux du point de vue évolutif et a probablement joué un rôle crucial dans l'élaboration de la distribution géographique de nombreux ravageurs des cultures récents.
\end{abstract}

(C) 2011 Académie des sciences. Publié par Elsevier Masson SAS. Tous droits réservés.

\footnotetext{
* Corresponding author.

E-mail address: guillem@sophia.inra.fr (T. Guillemaud).
}

\section{Introduction}

Biological invasions are major ecological phenomena that influence biodiversity by shaping the worldwide distribution of species. In recent times, they have become a 
significant element in global change and have been accused of having adverse effects on public health, the economy and biodiversity [1]. The development of human trade and transport since the 15th Century, which has accelerated over the last 200 years, has increased the importance of invasions as a cause of human-induced global change [2]. Invasive species are important vectors of emerging diseases [3], agricultural pests [4] and responsible for many species extinctions and changes in biodiversity worldwide (e.g. [5]).

Many studies on biological invasions have been published since the 1990s, but the definition of an invasive species remains vague. The terminology relating to biological invasions includes a plethora of terms and a wide variety of uses. For example, terms such as "introduction", "establishment" or "invasive species" have been used in different ways in previous publications [6,7]. The vocabulary associated with biological invasions suffers from two flaws: polysemy (multiple meanings for one word, e.g. "invasive") and synonymy (several words for one meaning, e.g. "alien", "exotic", "non indigenous", "introduced"). These problems partly account for the difficulties involved in finding a definition acceptable to most biologists. In addition, one of the problems encountered when trying to define the term "invasive species" arises from the tendency of the word "invasion" to evoke anthropocentric concepts (e.g. "Barbarian Invasions", assault, attack, intrusion, incursion, raid, etc.) [7] associated with negative connotations that may not necessarily apply to ecological phenomena. Current definitions differ in the relative importance attributed to three major components: 'range expansion' [8], 'high local abundance' [9] and 'disruption of ecosystem function' [10]. We will use the following definition here: an invasion may be considered to have occurred when a group of individuals has been introduced into a new area, in which they have established themselves, increased in number and spread geographically. This definition does not necessarily imply a spread into new ecological conditions and does not necessarily result in negative effects on the invaded ecosystem.

Many studies on this topic have been published, but only very few biological invasions have been properly described, studied and understood, due to conceptual, methodological and experimental limitations (e.g. [8]). Consequently, most of the hypotheses formulated concerning the key factors determining the probability of success or failure of invasions, such as propagule size, genetic variability or hybridization, have never been tested. One of the key scientific questions concerning biological invasions that has yet to be answered concerns the reasons why some species become successful invaders whereas others do not $[1,11]$. The general characteristics of species (such as dispersal, competitiveness) may determine the probability of the species becoming invasive [12]. There is, however, some intraspecific variation for this probability as illustrated by the observation that only a small fraction of populations becomes invasive in many "invasive species" (e.g. [13-15]). There is therefore still a need to identify explanatory evolutionary and environmental factors at the population level. We argue that the precise descriptions of biological invasions, including their history, geography, demography and genetics - referred to here as invasion routes - represent a first step toward identifying these factors.

We focus here on biological invasions in agricultural settings. We briefly review the specificity of invasions in agricultural settings and explain why the reconstruction of invasion routes can be used to address fundamental questions about the determinants of invasions and practical aspects of biological invasion management. We then consider the methodological challenges associated with studies of invasion routes and describe the main evolutionary and environmental insights drawn to date from the large set of published studies dealing with the reconstruction of invasion routes.

\section{Invasion in agricultural settings}

The history of agriculture is intimately linked to biological invasions. The invention and development of agriculture allowed the worldwide spread of human populations [16]. It also led to the invasion, as defined above, of areas by cultivated plants and livestock animals [17]. As a result, a few animal and plant species are now found throughout the world. Pimentel et al. [18] observed that agricultural activities have led to $90 \%$ of the food of the world's human population being provided by a mere 15 plant species, and eight animal species accounting for most of the animal proteins consumed by humans. Species such as maize (Zea mays) and chicken (Gallus gallus domesticus) are found all over the world (with the exception of hot and cold deserts) and their populations are much larger than that of humans (references in Pimentel et al. [18]).

A large number of animals, plants and microbes living in agricultural ecosystems decrease the quality and/or quantity of the cultivated resource and are therefore considered to be pest species. These pests are often recently introduced organisms capable of taking advantage of the extraordinarily large amount of resources provided by cultivated crops or animals for settlement and spread. In the absence of predators and parasites, invaders often undergo explosive population increases, with severe consequences for the crop plants and domesticated animals concerned. This results in the invader being classified as a major pest species. For example, the oomycete Phytophthora infestans, the causal agent of potato blight, was introduced into Europe from America around 1843 [19]. It invaded large cultivated areas of Europe and was the cause of the Great Famine in Ireland in the mid-19th Century. Another famous example is grape phylloxera, Daktulosphaira vitifoliae, which is a worldwide pest of grapevine [20]. This insect devastated European vineyards after its introduction in the region of Bordeaux, France, and its spread across Europe in the second half of the 19th Century. Similarly, Ceratitis capitata, the Mediterranean fruit fly, is a famous pest of fruit crops originating from Africa. It invaded the Americas and Australia during the late 19th and 20th centuries and is now one of the world's most threatening agricultural pests, attacking over 200 different cultivated plants [21]. Ten of the 16 invasive terrestrial invertebrates present in the DAISIE (a European 
consortium of researchers studying invasive species in Europe) "100 of the worst" list are crop pests [22].

The invasion of agricultural settings by pests may have tremendous economic and social consequences. Such invasions may generate costs due to production loss, decreases in the value of the product and the need for control practices (survey, containment, eradication). The estimated world cost of biological invasions in agriculture reaches the astronomical range of 50 to 250 billion US dollars per year [18]. Many social and economic activities have also developed to deal with this problem, from the chemical industry, genetic engineering development and agricultural advisory services to public and private agronomy research.

\subsection{Invasion and biological control}

Biological control is a promising approach to the control of pest species in agriculture, because it has few if any adverse effects on the environment and human health. Classical biological control (CBC) is a component of both integrated pest management and organic farming. It involves the introduction of an organism - often a predator or a parasite of the pest species targeted - into an area in which it was not previously found, in the hope of establishing stable populations capable of reducing the density of a specific pest [23]. CBC and invasion biology are intimately linked for at least two reasons:

\section{- the target of CBC is often an invading species that has} recently acquired pest status. A successful example of $\mathrm{CBC}$ against an invasive pest species is provided by the glassy-winged sharpshooter, Homalodisca vitripennis. This large leafhopper is a xylem-feeding pest that transmits Xelella fastidiosa, a parasitic bacterium responsible for a lethal infection in plants. This species originates from the South East USA and Northern Mexico, and has invaded a number of sites in the Pacific, including several archipelagos in French Polynesia, since 1999 [24-26]. A CBC operation was implemented in 2004, with Gonatocerus ashmeadi, a parasitoid wasp that parasitizes the eggs of the pest species. After the release of more than 10,000 individuals in Tahiti in 2005, invasive glassy-winged sharpshooter populations decreased in size by about $90 \%$ around the release sites [26];

- CBC and biological invasions have similar properties. CBC aims to establish and spread populations of beneficial species, through ecological processes resembling those occurring during unintentional invasions [27-29]. Biological invasions, which may be unintentional and detrimental (in the case of pest species) or intentional and beneficial (in the case of $\mathrm{CBC}$ ), have enough characteristics in common to be considered as a single eco-evolutionary process. Thus, an understanding of the ecological and genetic factors underlying efficient biological control may help us to understand and to manage detrimental biological invasions. Conversely, the information obtained from descriptions of accidental biological invasions may help us to design more effective biological control. In a CBC operation, the initial demographic (number of individuals, number of release points, timing of releases) and genetic (genetic variance and adaptive traits of the introduced population) parameters of the invasion - the introduction parameters - can be controlled experimentally [30,31]. Meta-analyses of ancient $\mathrm{CBC}$ successes and failures have been used to address certain questions [32], but CBC can also be used in natura, in the design of specific experiments testing biological invasion hypotheses. This approach has seldom been used, but has recently begun to drive the use of $\mathrm{CBC}$ in model experiments. A recent example is provided by the work of Fauvergue et al. [33], who manipulated the demographic characteristics of a parasitoid introduced in a CBC context to test for a positive effect of the size of the population introduced on the success of establishment and, hence, of invasion. These authors introduced the North American parasitoid Neodryinus typhlocybae into Southern France, to control the North American invasive flatid planthopper, Metcalfa pruinosa, and demonstrated a total absence of the expected positive demographic effect on the success of settlement [33].

\subsection{Factors promoting invasions}

\subsubsection{Role of humans in shaping invasion routes}

Human activities are responsible for a large proportion of recent biological invasions [34] in two main ways. First, human activities serve as a vector for the introduction of propagules (canals, marine ballast, air, road and train traffic) into new, geographically disconnected areas and for geographic expansion of populations that have already been introduced (see p. 21 of [35]). The second role of human activities in promoting biological invasions involves environmental modification. The disturbance of natural habitats by human activities is thought to facilitate bioinvasions [36] and disturbances due to agriculture development may play a particular role in this respect $[37,38]$. Agriculture has a particular consequence in terms of habitat disturbance: it has homogenized the environment worldwide. The cultivation of domesticated plants, such as maize, has homogenized habitats, decreasing ecological differences between regions in different parts of the world, from Africa to Asia, and from North and South America to Europe [39]. When a species is introduced into a new and remote area, the expected mismatch between its phenotypic characteristics and local ecological conditions is greatly attenuated by this homogenization.

\subsubsection{Adaptation}

Natural selection and adaptation probably play key roles in determining the success of invasion during the establishment phase $[40,41]$. In the absence of strong environmental homogenization, the new geographic area into which individuals are introduced may have ecological conditions very different from those of the native area. A large additive genetic variance in the introduced population should increase adaptability, thereby increasing the probability of settlement and subsequent demographic growth and geographic spread (e.g. [8]). However, adaptation may also occur in populations with low levels of genetic variation, provided that "good" genetic combinations are present [8]. This is particularly true in 
agricultural contexts, in which the selection pressure exerted by pest control strategies may be very strong (see p. 128 of [35]). For example, pesticide resistance may be the main prerequisite for the settlement and spread of introduced pests in areas commonly treated with one or more pesticides to control resident pests. In the aphid Aphis gossypii, a pest of many cultivated plants (cotton, melon, potato, pepper, eggplant, citrus, etc.), a few genetic clones have spread worldwide. These clones are adapted both to their host plants - they display an intimate degree of host specialization [42] - and to the most common pesticide treatments, with most clones resistant to organophosphate and pyrethroid insecticides [43]. The spread of the western corn rootworm, Diabrotica virgifera virgifera, in the US during the 1960s probably resulted from the appearance and spread of allelic forms conferring insecticide resistance [44]. This insect pest of maize has been present in the Great Plains since at least 1867, and by 1955, its geographic distribution remained limited to parts of Kansas, Colorado and Nebraska [45]. Cyclodiene insecticides were introduced in 1952 and were massively used, and the first reported case of resistance occurred in 1959 [44]. Resistant rootworm rapidly spread throughout the Corn Belt and reached Northwest Indiana in 1968. In 1979, it was present throughout most of the US Corn Belt, from Nebraska to Ohio and from Minnesota to Missouri [44,45]. It has not been demonstrated that insecticide resistance was responsible for accelerating the geographic spread of the western corn rootworm in the 1960s [45], but it is nonetheless clear that this spread would not have been possible if the insects had not evolved cyclodiene resistance.

\subsection{Routes of invasion}

\subsubsection{An approach to tackling academic issues}

The genetic variability of invading populations depends on the history and demography of the populations or groups of individuals, from their emigration from the source population to their introduction and spread [46]. The description of this history depicts invasion routes. It includes information about source populations (number and genetic composition), the number of introductions from the sources, the number of individuals involved in each introduction, the occurrence of admixture between independently introduced populations, the number of intermediate invasive populations between the initial introduction point and the invasive population studied and demographic dynamics at each step in the history of the invasion. In a recent review on this topic, Estoup and Guillemaud [47] argued that knowledge of invasion routes was required to decipher the factors responsible for the success of invasions. More specifically, information about sources and invasion pathways is essential if we are to avoid making erroneous conclusions when testing the hypothesis that a particular environmental or evolutionary factor affects invasion success. Keller and Taylor [48] argued that adaptive evolution could not be inferred from the simple observation of changes in the distribution of phenotypic traits between the invaded and the native area. They pointed out that the hypothesis of neutral evolution during invasion processes could only be rejected if ancestor-descendent comparisons or Qst-Fst analyses are carried out. Estoup and Guillemaud [47] also argued that such analyses need to compare "comparable entities" (here, the invasive populations and their precise source(s)), which requires a basic knowledge of invasion routes.

\subsubsection{An approach to tackling practical issues in agricultural settings}

The reconstruction of routes of invasion can contribute to the development or optimization of measures for preventing invasions, particularly in an agricultural context, in two main ways. Firstly, invasion routes basically describe the geographic origins of invasive pests until their introduction. This geographic information can be used as the basis of management actions directed against the main steps of the invasion process: exit from the native area (emigration), vector transport or migration and entry into the invasion site (see Introduction). In the case of recurrent introductions, as demonstrated for the chrysomelid $D$. virgifera [49], identification of the precise location of the escape path in the native area (e.g. a specific airport, harbor, ecosystem, region etc.) can lead to the design of specific monitoring and quarantine measures targeting the sources [17]. The same rationale can be applied to the vectors responsible for recurrent introductions and to the entry portals for the pest: control strategies focusing on specific vectors (e.g. freight containers of a particular crop seed or a specific human mode of transportation) or entry locations (e.g. a specific airport, harbor, ecosystem, region etc. as in the case of "exit doors"). By contrast, for pests arriving in a new area through a single or a small number of introduction events, eradication or containment strategies may be efficient if applied shortly after the arrival of the pest [17].

Secondly, identification of the invasion route provides information about the original environment and the genetic properties of the source population of the invading pest. A knowledge of the biotic and abiotic environment to which the pest is adapted may make it easier to design an effective control strategy. This is particularly true when choosing pesticides, as this choice must take into account the potential resistance of the source population. This simple rationale applies to all strategies for which susceptibility varies within the source populations of the pest (e.g. parasite or predator use, crop rotation). In the context of biological control, the choice of natural enemy to be introduced may depend on what we know about the source populations of the invader. Generally, the aim is to choose species or populations of a species with the same geographic origin as the pest population [35]. The probability of an invasive pest being controlled by a natural enemy depends on the level of adaptation of the two protagonists to their environment, their adaptation to each other and their ability to evolve $[29,50]$. In particular, biological control agents may be more effective against the native populations with which they coevolved and to which they have adapted than against other populations (see for a complication of the simple case $[15,29])$. 
Version définitive du manuscrit publiée dans / Final version of the manuscript published in :

Comptes Rendus Biologies (2011). Vol.334. N.3. p..237-246. DOI: 10.1016/i.crvi.2010.12.008

Journal homepage: www.sciencedirect.cōm

Box 1. Methods for reconstructing invasion routes.

The methods for reconstructing invasion routes have been described in detail elsewhere $[47,55]$ and are not affected by their application to agricultural settings. There are two types of methods: direct methods based on historical and observational data and indirect methods based on population genetics data. Direct methods have long been used and can be informative (e.g. [4]). However, they are often imprecise and depend on observations that are rare and/or difficult to obtain. Indirect methods are based on genetic data obtained in invasive and native populations, through the use of molecular markers (e.g. $[13,21]$ ). Based on comparisons of simple genetic statistics or more elaborate model-based statistical analyses, these indirect methods can be used to infer historical relationships between populations, such as "population $B$ is derived from population $A^{\text {" }}$ or "population $A$ is the result of hybridization between population $B$ and $C^{\prime \prime}$. A modelbased Bayesian approach, the approximate Bayesian computation (ABC) approach, has recently been developed [75] and adapted for invasion route inference [55]. This new methodology has two advantages over most other indirect methods:

- it takes into account the stochasticity of the demographic and genetic history considered;

- it makes it possible to estimate confidence in invasion route inference by calculating a probability for each alternative invasion route tested [47].

\subsubsection{Mistakes to avoid when retracing invasion routes}

Several problems may occur during the reconstruction of invasion routes, leading to erroneous conclusions. Whatever the method used (see Box 1), inappropriate. sampling schemes may be problematic. Muirhead et al. [51] reviewed published studies of invasion based on mitochondrial or chloroplast DNA markers and noticed. that the introduced and native populations were not generally sampled with the same intensity. In general, fewer indivicluals were sampled from populations collected from the native area ( $60 \%$ of the studies sampled a mean of fewer than six individuals per native population), but a larger number of populations were sampled in the native area. Verbal models and simulations have shown that the sampling of too few individuals from native populations or of too few native populations probably leads to the erroneous characterization of source populations of invaders [51]. Accuracy in the determination of the source population is also strongly dependent on spatial genetic structure in the native area $[51,52]$, with greater genetic differentiation between native populations generally ensuring more accurate source determination. As pointed out by Geller et al. [52] if there is strong local genetic differentiation, then source determination is theoretically optimal. However, in this case, the sampling efforts required to ensure that the real source population is not missed may be so great that "genetic methods will be unable to determine any likely source at all" (see Fig. 2 in [52]). Temporal variation in genetic structure may also lead to the misidentification of source populations. Allele frequencies for genetic probably vary significantly over

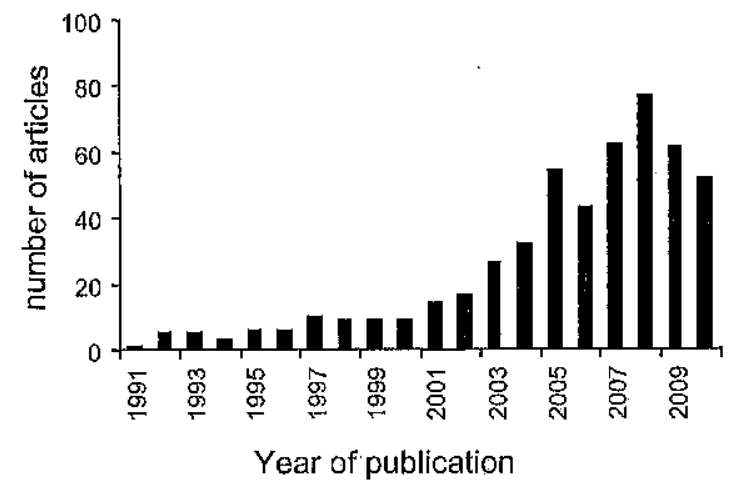

Fig. 1. Change over time in the number of scientific articles published on invasion routes. The pool of articles searched consisted of those published between 1975 and August 2010 present in the SCI-EXPANDED, SSCI, A\&HCI, CPCI-S, CPCI-SSH, CCR-EXPANDED and IC databases of ISI Web of Knowledge. The following keyword formula was used to search for target articles: Topic $=([$ invasi* or alien or exoti* $]$ and $[$ pathway* or route* or source*] and [genet* or "molecular marker" or microsatellite or mitochond* or choroplast ${ }^{*}$ ] and [ecolog* or population] not [cancer or medicin* or therap* ${ }^{*}$ ).

time in both the native and introduced area if there is a large amount of drift (i.e. for small populations, see [52]).

Other potential problems are direct consequences of the methods used to reconstruct invasion routes. Most methods, whether clirect or indirect (Box 1), cannot resolve complex invasion routes. For example, recurrent introductions from the same source (e.g. in D. virgifera [49]), admixture between various introduced populations and intermediate invasive populations playing the role of source populations (e.g. in $H$. axyridis [53]) are particular features that are difficult to consider with most genetic methods of inference, particularly those based on the calculation of genetic distances only [47]. Lombaert et al. [53] simulated invasive populations originating from the admixture between two source populations and applied classical methods based on assignment likelihood and the calculation of Fst to determine their source (e.g. [54]). In this particular but not unusual case, most of the results obtained were false, with the correct source being identified only rarely. Guillemaud et al. [55] also simulated genetic data with an intermediate introduced population serving as the source of two invading populations. Classical analyses often concluded that there have been multiple introductions from the native area when all the invaders actually originated from a single introduction into the invaded area. However, the complex scenarios described above can be correctly treated by the $A B C$ method described in Box 1, with DIYABC software, for example $[56,57]$.

\subsection{Common invasion scenarios}

The retracing of invasion routes from molecular genetic data is increasingly being carried out (Fig. 1). More than 500 scientific articles have been published on this subject since 1991, with more than 40 papers per year on this theme published since 2005. The results obtained for invasion route descriptions are extremely variable, but three general trends can be observed: 
Version définitive du manuscrit publiée dans / Final version of the manuscript published in :

Comptes Rendus Biologies (2011), Vol. 334, No.3, p. 237-246, DOI: 10.1016/j-crvi.2010.12.008

Journal homepage: www.sciencedirect.com

A

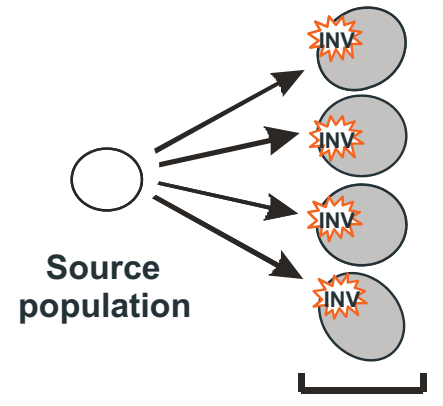

Invasive populations resulting from multiple introductions

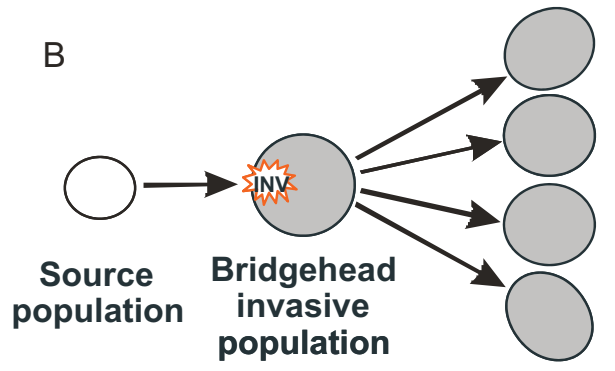

Fig. 2. Origin of the invasive characteristics of invasive populations resulting from multiple introductions. A. Standard scenario of multiple introductions requiring multiple acquisitions of invasive traits. B. "Bridgehead invasion" scenario with a single acquisition of invasive characteristics in the intermediate bridgehead invasive population. Populations in gray are invasive. Arrows indicate introduction events, "Inv" refers to the evolution of invasive traits.

\subsubsection{Multiple introductions}

Recent papers on invasion routes suggest that invasions are often associated with multiple introductions (i.e. several introductions from one or several sources into one or several remote areas). This scenario has been demonstrated in the cases of the maize pest $D$. virgifera [13,49], the false brome Brachypodium sylvaticum [58], the spotted knapweed Centaurea stoebe micranthos [59], the shrub Scotch broom [15], the mosquito Culex quiquefasciatus [60], the amphipod Gammarus tigrinus [14], the Cuban lizard [61], the freshwater snail M. tuberculata [62], and many other invasive species [63].

\subsubsection{Admixture}

Studies using indirect genetic methods to reconstruct invasion routes have suggested that admixtures between different source populations often occur in invasions, as demonstrated principally in plants (e.g. [58]) although this scenario has also been reported for a number of invasive animals, including the Cuban lizard [64], the freshwater snail Melanoides tuberculata [65], and the harlequin ladybeetle Harmonia axyridis [53].

\subsubsection{Bridgehead effect}

In a number of articles describing invasion routes, successful invasive populations appear to originate from an intermediate population, which is, itself, a successful invasive population $[49,61,66-68]$. In this scenario, the intermediate invasive population at the origin of the secondary invasive populations plays the role of a bridgehead. As described below, this "invasion bridgehead", is particularly important for an understanding of how and why invasions occur in agricultural settings. As suggested by Facon et al. [11], several factors are required to account for the occurrence of an invasion:

- a change in migration regime;

- an environmental change in the area into which the species is introduced;

- a genetic change in the introduced population leading to a new match between the environment and the introduced individuals.

Let us consider an invasion scenario including multiple introductions, in which an evolutionary genetic change

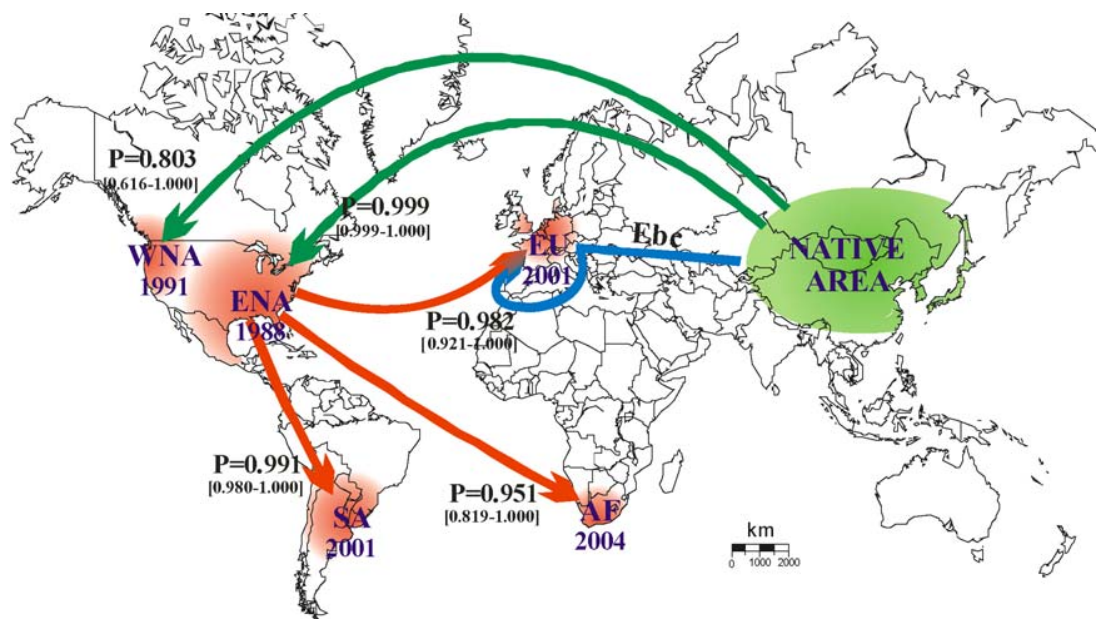

Fig. 3. Most likely invasion routes of Harmonia axyridis, deduced from genetic analysis based on microsatellite markers variation and approximate Bayesian computation by Lombaert et al. [53]. For each outbreak, the arrow indicates the most likely invasion pathway and the associated posterior probability value (P), with 95\% confidence intervals in brackets. The years in which the invasive populations were first observed are indicated. 
Box 2. Bridgehead invasion in the biocontrol agent Harmonia axyridis.

\begin{abstract}
The Harlequin ladybeetle or multicolored Asian lady beetle, Harmonia axyridis, a native of Asia, has long been used as a biological control agent to control aphid populations. Despite repeated attempts at introduction since 1916, the establishment of this species was not observed until recently (references in Lombaert et al. [53]). In 1988 and 1999, the first invasive populations were recorded in Louisiana and Oregon, respectively. Invasive populations of the Asian ladybeetle were then observed in Europe (Belgium in 2001) and South America (Argentina in 2001), followed by South Africa in 2004. Using molecular markers, historical information and ABC methods, Lombaert et al. [53] showed that the invasive populations in western and eastern North America arose from two introductions from Asia, either through biological control or accidental introductions, and that the European, South American and African outbreaks all originated independently from eastern North America. In addition, evidence of an admixture between the eastern North American population and the native Asian population were found in Europe. The invasion routes summarized in Fig. 3 indicate that the eastern North American invasive population acted as a bridgehead population in the worldwide invasion of $H$. axyridis. The role of eastern North America in the sudden invasion of Europe, South America and Africa, the long history of unsuccessful introductions of the ladybeetle from its native range for biological control, and the apparent absence of invasive populations originating from western North America suggest that an evolutionary change or a change in emigration regime probably occurred in eastern North America. Additional quantitative genetics studies of key life history traits are underway.
\end{abstract}

accounts for the success of invasion. Without a bridgehead population, the framework of Facon et al. [11] requires multiple genetic shifts (one in each introduced area, Fig. $2 \mathrm{~A})$. In a bridgehead invasion scenario, only one evolutionary shift toward invasiveness has to occur in the bridgehead population (Fig. 2B). This scenario is therefore evolutionarily more parsimonious than that without a bridgehead. Two illustrative example of a bridgehead invasion scenario are given in Boxes 2 and 3.

How general are bridgehead invasion scenarios? Apart from the studies on D. virgifera and H. axyridis (Boxes 2 and 3 ), other studies have shown that intermediate invasive populations may be the sources of other, often distant, invasive populations $[61,66,69]$. However, it is possible to demonstrate the occurrence of such scenarios only in very well documented cases of biological invasions: demonstrating the existence of a "bridgehead" population requires a good knowledge of the geographic distribution of the species (native and invaded areas) and of the routes of invasion of the species. Crop pests probably commonly establish bridgehead populations. We found several examples of pests or pathogens for which precise documentation of the invasion made it possible to identify
Box 3. Bridgehead invasion of the western corn rootworm, Diabrotica virgifera virgifera.

This chrysomelid, a pest that attacks the root system of maize, is one of the most important pests of maize in the USA and is sometimes referred to as the "billion dollar bug" [76]. It originates from what we now call Mexico, was first observed in the US in 1867, in the Great Plains, and invaded North America during the second half of the 20th century [45]. It was first observed in Europe in 1992, in the former Yugoslavia, and rapidly invaded a large part of Central and South Eastern Europe. A number of isolated outbreaks have been detected almost every year since 1998, in various countries, including Italy, France, Switzerland, Belgium, the United Kingdom, the Netherlands and Germany [77]. Using molecular markers and historical information, Miller et al. [49] and Ciosi et al. [13] showed that the invasion of Europe by $D$. virgifera was very probably due to multiple introductions from North America and, more precisely, from the Northern US [13]. The invasions of North America and Europe by this agricultural pest thus form a succession of introductions and geographic expansions and correspond to a bridgehead invasion scenario: the native Mexican population gave rise to an invasive bridgehead population in the US, which acted as the source of all the other invasive populations in Europe. We propose the following hypotheses for invasion by $D$. virgifera: after its introduction from the Mexican source population into the US, invasion by the North American bridgehead population was triggered by one or more adaptive changes, such as specialization on a widespread resource (in this case, maize). A change in emigration regime in the bridgehead population when it reached the North East US was then sufficient to initiate remote invasions in Europe.

a bridgehead population, or at least to show that the likely scenario involved an intermediate invasive population giving rise to several secondary invasions. A non-exhaustive list of examples is provided below:

- potato blight, Phytophthora infestans, was introduced into Europe in the $1840 \mathrm{~s}$ from America (references in [19]). Goodwin et al. [70] suggested that the European population then served as the source population for a number of other introductions, resulting in the worldwide distribution of this oomycete;

- the causal agent of apple scab, Venturia inaequalis, invaded the world by following its host [71]. It originated in Central Asia, and was first introduced into Europe during the Ancient history. Europe then acted as a secondary source for world colonization by the pathogen over the last 500 years;

- the European corn borer, Ostrinia nubilalis first invaded Europe, establishing a bridgehead from which it was subsequently introduced into North America [72,73];

- the Colorado beetle, Leptinotarsa decemlineata first invaded the United States. It was then introduced into Europe [69]; 
- the grape phylloxera, Daktulosphaira vitifoliae, in addition to invading the whole of Europe from France, probably initially invaded California, subsequently being introduced, from the American population, into Australia, New Zealand and Peru [66];

- the Guatemalan potato moth, Tecia solanivora, first invaded the southern part of Central America and, from there, was introduced into South America and the Canary Islands [74].

Most of the species mentioned above, like $D$. virgifera (see Box 2), probably achieved pest status following an evolutionary shift allowing the bridgehead population to become invasive: adaptation to a cultivated plant. $D$. virgifera and the European corn borer probably left several wild herbaceous hosts to adapt to maize. The Colorado beetle, the Guatemalan potato moth and the potato blight probably all moved onto the cultivated potato from wild tuber-bearing plants. Phylloxera may not have adapted: this aphid became a major pest on grapes because the Vitis species used happened to be susceptible. In this case, a change in migration regime was probably the cause of the secondary introductions worldwide from California. Once it was discovered that the American Vitis species could be used as a rootstock for the efficient control of phylloxera, the intensive collection and exchange of American native Vitis plants occurred, undoubtedly increasing the number of phylloxera introductions worldwide [66]. In the case of apple scab, the global codispersal of apple and its pathogen probably provides the best explanation of the current worldwide distribution of Venturia inaequalis. This scenario reflects a major change in the migration regime of the pathogen due to the colonization of the rest of the world by European settlers.

\section{Conclusion}

The histories of invasions and agriculture are intimately linked, with many crop and livestock pests being invasive species and vice versa. In addition, some pest management practices essentially constitute intentional and beneficial invasions. Such practices require a precise knowledge of invasion biology and, conversely, their application may provide valuable information about invasion biology. Recent methods based on analyses of genetic markers have provided tools for the retracing of invasion routes - the history of the invading populations from their geographic origin to their final spread in the invaded area. The examples for which a precise description of invasion routes at the global level is available provide new insight into invasion biology and have highlighted previously unsuspected global trends. In particular the bridgehead invasion scenario seems to apply to many cases of pest invasions and merits more thorough consideration when trying to explain the distribution of other invasive species in agricultural settings. The number of publications on the invasion routes of crop and livestock pests and pathogens is growing, and future studies in this field will undoubtedly provide valuable information challenging the generalization of this evolutionary scenario.

\section{Conflicts of interest statement}

The authors declared no conflict of interest.

\section{Acknowledgments}

This work was supported by grants from the Agence nationale de la recherche (ANR-06-BDIV-008-01 and ANR09-BLAN-0145-01) and from the Agropolis Fondation (RTRA-Montpellier, BIOFIS project).

\section{References}

[1] D.F. Sax, J.J. Stachowicz, S.D. Gaines, Species Invasions: insights into Ecology, Evolution, and Biogeography, Sinauer Associates, Sunderland, MA, U. S. A., 2005.

[2] J.M. Jeschke, D.L. Strayer, Invasion success of vertebrates in Europe and North America, Proc. Natl. Acad. Sci. U. S. A. 102 (2005) 7198-7202.

[3] R. Eritja, R. Escosa, J. Lucientes, E. Marques, R. Molina, D. Roiz, S. Ruiz, Worldwide invasion of vector mosquitoes: present European distribution and challenges for Spain, Biol. Invasions 7 (2005) 87-97.

[4] T.T. Work, D.G. McCullough, J.F. Cavey, R. Komsa, Arrival rate of nonindigenous insect species into the United States through foreign trade, Biol. Invasions 7 (2005) 323-332.

[5] A. Alyokhin, G. Sewell, Changes in a lady beetle community following the establishment of three alien species, Biol. Invasions 6 (2004) 463471.

[6] R.I. Colautti, H.J. MacIsaac, A neutral terminology to define 'invasive' species, Divers. Distrib. 10 (2004) 135-141.

[7] D.M. Richardson, P. Pysek, M. Rejmanek, M.G. Barbour, F.D. Panetta, C.J West, Naturalization and invasion of alien plants: concepts and definitions, Divers. Distrib. 6 (2000) 93-107.

[8] B. Facon, B. Genton, J. Shyckoff, P. Jarne, A. Estoup, P. David, A general eco-evolutionary framework for understanding biological invasions, Trends Ecol. Evol. 21 (2006) 130-135.

[9] A. Suarez, N. Tsutsui, D. Holway, T. Case, Behavioral and genetic differentiation between native and introduced populations of the Argentine ant, Biol. Invasions 1 (1999) 43-53.

[10] H. Mooney, R. Hobbs, Invasive species in a changing world, Island Press, Washington D. C., 2000.

[11] M.W. Cadotte, S.M. McMahon, T. Fukami, Conceptual Ecology and Invasion Biology: reciprocal Approaches to Nature, Springer, Dordrecht, The Netherlands, 2006.

[12] A.K. Sakai, F.W. Allendorf, J.S. Holt, D.M. Lodge, J. Molofsky, K.A. With, S. Baughman, R.J. Cabin, J.E. Cohen, N.C. Ellstrand, D.E. McCauley, P. O'Neil I.M. Parker, J.N. Thompson, S.G. Weller, The population biology of invasive species, Annu. Rev. Ecol. Syst. 32 (2001) 305-332.

[13] M. Ciosi, N.J. Miller, K.S. Kim, R. Giordano, A. Estoup, T. Guillemaud, Invasion of Europe by the western corn rootworm, Diabrotica virgifera virgifera: multiple transatlantic introductions with various reductions of genetic diversity, Mol. Ecol. 17 (2008) 3614-3627.

[14] D.W. Kelly, J.R. Muirhead, D.D. Heath, H.J. Macisaac, Contrasting patterns in genetic diversity following multiple invasions of fresh and brackish waters, Mol. Ecol. 15 (2006) 3641-3653.

[15] M. Kang, Y.M. Buckley, A.J. Lowe, Testing the role of genetic factors across multiple independent invasions of the shrub Scotch broom (Cytisus scoparius), Mol. Ecol. 16 (2007) 4662-4673.

[16] A. Ammerman, L.L. Cavalli-Sforza, The Neolithic transition and the genetics of populations in Europe,, Princeton University Press, Princeton, NJ, 1984.

[17] R.N. Mack, D. Simberloff, W.M. Lonsdale, H. Evans, M. Clout, F.A. Bazzaz, Biotic invasions: causes, epidemiology, global consequences, and control, Ecol. Appl. 10 (2000) 689-710.

[18] D. Pimentel, S. McNair, J. Janecka, J. Wightman, C. Simmonds, C. O'Connell, E. Wong, L. Russel, J. Zern, T. Aquino, T. Tsomondo, Economic and environmental threats of alien plant, animal, and microbe invasions, Agric. Ecosyst. Environ. 84 (2001) 1-20.

[19] D. Andrivon, The origin of Phytophthora infestans populations present in Europe in the 1840s: a critical review of historical and scientific evidence, Plant Pathol. 45 (1996) 1027-1035. 
[20] J. Granett, M.A. Walker, L. Kocsis, A.D. Omer, Biology and management of grape phylloxera, Annu. Rev. Entomol. 46 (2001) 387-412.

[21] N. Davies, F.X. Villablanca, G.K. Roderick, Bioinvasions of the medfly Ceratitis capitata: source estimation using DNA sequences at multiple intron loci, Genetics 153 (1999) 351-360.

[22] DAISIE, Handbook of Alien Species in Europe, Springer, Dordrecht, 2009.

[23] J. Eilenberg, A.L.C. Hajek, Suggestions for unifying the terminology in biological control, Biol. Control 46 (2001) 387-400.

[24] J. Grandgirard, M.S. Hoddle, J.N. Petit, G.K. Roderick, N. Davies, Classical biological control of the glassy-winged sharpshooter, Homalodisca vitripennis, by the egg parasitoid Gonatocerus ashmeadi in the Society. Marquesas and Austral archipelagos of French Polynesia, Biol. Control 48 (2009) 155-163.

[25] J.N. Petit, M.S. Hoddle, J. Grandgirard, G.K. Roderick, N. Davies, Invasion dynamics of the glassy-winged sharpshooter Homalodisca vitripennis (Germar) (Hemiptera: Cicadellidae) in French Polynesia, Biol. Invasions 10 (2008) 955-967.

[26] J.N. Petit, M.S. Hoddle, J. Grandgirard, G.K. Roderick, N. Davies, Shortdistance dispersal behavior and establishment of the parasitoid Gonatocerus ashmeadi (Hymenoptera: Mymaridae) in Tahiti: Implications for its use as a biological control agent against Homalodisca vitripennis (Hemiptera: Cicadellidae), Biol. Control 45 (2008) 344-352.

[27] L.E. Ehler, Invasion biology and biological control, Biol. Control 13 (1998) 127-133.

[28] W.F. Fagan, M.A. Lewis, M.G. Neubert, P. van den Driessche, Invasion theory and biological control, Ecol. Lett. 5 (2002) 148-157.

[29] G.K. Roderick, M. Navajas, Genes in new environments: genetics and evolution in biological control, Nat. Rev. Genet. 4 (2003) 889-899.

[30] F.S. Grevstad, Experimental invasions using biological control introductions: the influence of release size on the chance of population establishment, Biol. Invasions 1 (1999) 313-323.

[31] J. Memmott, P.G. Craze, H.M. Harman, P. Syrett, S.V. Fowler, The effect of propagule size on the invasion of an alien insect, J. Anim. Ecol. 74 (2005) 50-62.

[32] K.R. Hopper, R.T. Roush, Mate finding, dispersal, number released, and the success of biological introduction, Ecol. Entomol. 18 (1993) 321331.

[33] X. Fauvergue, J.C. Malausa, L. Giuge, F. Courchamp, Invading parasitoids suffer no allee effect: a manipulative field experiment, Ecology 88 (2007) 2392-2403.

[34] J.L. Lockwood, P. Cassey, T. Blackburn, The role of propagule pressure in explaining species invasions, Trends Ecol. Evol. 20 (2005) 223-228.

[35] G.W. Cox, Alien Species and Evolution: the evolutionary ecology of exotic plants, animals, microbes, and interacting native species, Island Press, Washigton, 2004.

[36] J.C Lake, M.R. Leishman, Invasion success of exotic in natural ecosystems: the role of disturbance, plant attributes and freedom from herbivores, Biol. Conserv. 117 (2004) 215-226.

[37] J.L. Lockwood, M.F. Hoopes, M.P. Mearchetti, Invasion ecology, Blackwell Publishing, Malden, MA, 2007.

[38] D. Tilman, J. Fargione, B. Wolff, C. D’Antonio, A. Dobson, R. Howarth, D. Schindler, W.H. Schlesinger, D. Simberloff, D. Swackhamer, Forecasting agriculturally driven global environmental change, Science 292 (2001) 281-284.

[39] Anonymous, Maize in human nutrition, Food and Agriculture Organization of the United nations, Rome, 1993.

[40] D.N. Reznick, C.K. Ghalambor, The population ecology of contemporary adaptations: what empirical studies reveal about the conditions that promote adaptive evolution, Genetica 112 (2001) 183-198.

[41] K.A. Schierenbeck, M.L. Aïnouche, The role of evolutionary genetics in studies of plant invasions, in : M.W. Cadotte, S.M. McMahon, T. Fukami (Eds.), Conceptual ecology and invasion biology: reciprocal approaches to nature, Springer, Dordrech, The Netherlands, 2006, pp. 193-221.

[42] J. Carletto, E. Lombaert, P. Chavigny, T. Brevault, L. Lapchin, F. Vanlerberghe-Masutti, Ecological specialization of the aphid Aphis gossypii glover on cultivated host plants, Mol. Ecol. 18 (2009) 2198-2212.

[43] J. Carletto, T. Martin, F. Vanlerberghe-Masutti, T. Brevault, Insecticide resistance traits differ among and within host races in Aphis gossypii, Pest Manag. Sci. 66 (2010) 301-307.

[44] R.L. Metcalf, Implications and prognosis of resistance to insecticides, in : G.P. Georghio, T. Saito (Eds.), Pest resistance to pesticides, Plenum, New York, NY, 1983, pp. 703-733.

[45] M.E. Gray, T.W. Sappington, N.J. Miller, J. Moeser, M.O. Bohn, Adaptation and invasiveness of Western Corn rootworm: intensifying research on a worsening pest, Annu. Rev. Entomol. 54 (2009) 303-321.

[46] K.M. Dlugosch, I.M. Parker, Founding events in species invasions: genetic variation, adaptive evolution, and the role of multiple introductions, Mol. Ecol. 17 (2008) 431-449.
[47] A. Estoup, T. Guillemaud, Reconstructing the routes of invasion: what for, how and so what? Mol. Ecol. 19 (2010) 4113-4130.

[48] S.R. Keller, D.R. Taylor, History, chance and adaptation during biological invasion: separating stochastic phenotypic evolution from response to selection, Ecol. Lett. 11 (2008) 852-866.

[49] N. Miller, A. Estoup, S. Toepfer, D. Bourguet, L. Lapchin, S. Derridj, K.S. Kim, P. Reynaud, L. Furlan, T. Guillemaud, Multiple transatlantic introductions of the western corn rootworm, Science 310 (2005) 992-1992.

[50] I.M. Parker, G.S. Gilbert, The evolutionary ecology of novel plantpathogen interactions, Annu. Rev. Ecol. Evol. Syst. 35 (2004) 675-700.

[51] J.R. Muirhead, D.K. Gray, D.W. Kelly, S.M. Ellis, D.D. Heath, H.J. Macisaac, Identifying the source of species invasions: sampling intensity vs. genetic diversity, Mol. Ecol. 17 (2008) 1020-1035.

[52] J.B. Geller, J.A. Darling, J.T. Carlton, Genetic perspectives on marine biological invasions, Annu. Rev. Mar. Sci. 2 (2010) 367-393.

[53] E. Lombaert, T. Guillemaud, J.M. Cornuet, T. Malausa, B. Facon, A. Estoup, Bridgehead effect in the worldwide invasion of the biocontrol harlequin ladybird, Plos One 5 (2010) e9743.

[54] M. Pascual, M.P. Chapuis, F. Mestres, J. Balanya, R.B. Huey, G.W. Gilchrist, L. Serra, A. Estoup, Introduction history of Drosophila subobscura in the New World: a microsatellite-based survey using ABC methods, Mol. Ecol. 16 (2007) 3069-3083.

[55] T. Guillemaud, M.A. Beaumont, M. Ciosi, J.M. Cornuet, A. Estoup, Inferring introduction routes of invasive species using approximate Bayesian computation on microsatellite data, Heredity 104 (2010) 8899.

[56] J.M. Cornuet, V. Ravigne, A. Estoup, Inference on population history and model checking using DNA sequence and microsatellite data with the software DIYABC (v1.0), BMC Bioinformatics 11 (2010).

[57] J.M. Cornuet, F. Santos, M.A. Beaumont, C.P. Robert, J.M. Marin, D.J. Balding, T. Guillemaud, A. Estoup, Inferring population history with DIY ABC: a user-friendly approach to approximate Bayesian computation, Bioinformatics 24 (2008) 2713-2719.

[58] D.M. Rosenthal, A.P. Ramakrishnan, M.B. Cruzan, Evidence for multiple sources of invasion and intraspecific hybridization in Brachypodium sylvaticum (Hudson) Beauv. in North America, Mol. Ecol. 17 (2008) 4657-4669.

[59] R.A. Marrs, R. Sforza, R.A. Hufbauer, Evidence for multiple introductions of Centaurea stoebe micranthos (spotted knapweed, Asteraceae) to North America, Mol. Ecol. 17 (2008) 4197-4208.

[60] D.M. Fonseca, D.A. LaPointe, R.C. Fleischer, Bottlenecks and multiple introductions: population genetics of the vector of avian malaria in Hawaii, Mol. Ecol. 9 (2000) 1803-1814.

[61] J.J. Kolbe, R.E. Glor, L.R.G. Schettino, A.C. Lara, A. Larson, J.B. Losos, Genetic variation increases during biological invasion by a Cuban lizard, Nature 431 (2004) 177-181.

[62] B. Facon, J.-P. Pointier, M. Glaubrecht, C. Poux, P. Jarne, P. David, A molecular phylogeography approach to biological invasions of the New World by parthenogenetic thiarid snails, Mol. Ecol. 12 (2003) 30273039.

[63] O. Bossdorf, H. Auge, L. Lafuma, W.E. Rogers, E. Siemann, D. Prati, Phenotypic and genetic differentiation between native and introduced plant populations, Oecologia 144 (2005) 1-11.

[64] J.J. Kolbe, A. Larson, J.B. Losos, Differential admixture shapes morphological variation among invasive populations of the lizard Anolis sagrei, Mol. Ecol. 16 (2007) 1579-1591.

[65] B. Facon, P. Jarne, J.P. Pointier, P. David, Hybridization and invasiveness in the freshwater snail Melanoides tuberculata: hybrid vigour is more important than increase in genetic variance, J. Evolution. Biol. 18 (2005) 524-535.

[66] D.A. Downie, Locating the sources of an invasive pest, grape phylloxera, using a mitochondrial DNA gene genealogy, Mol. Ecol. 11 (2002) 20132026.

[67] O. Floerl, G.J. Inglis, K. Dey, A. Smith, The importance of transport hubs in stepping-stone invasions, J. Appl. Ecol. 46 (2009) 37-45.

[68] B. Hanfling, G.R. Carvalho, R. Brandl, mt-DNA sequences and possible invasion pathways of the Chinese mitten crab, Mar. Ecol. Prog. Ser. 238 (2002) 307-310.

[69] A. Grapputo, S. Boman, L. Lindstrom, A. Lyytinen, J. Mappes, The voyage of an invasive species across continents: genetic diversity of North American and European colorado potato beetle populations, Mol. Ecol. 14 (2005) 4207-4219.

[70] S.B. Goodwin, B.A. Cohen, W.E. Fry, Panglobal Distribution of a Single Clonal lineage of the irish potato famine fungus, Proc. Natl. Acad. Sci. U. S. A. 91 (1994) 11591-11595.

[71] P. Gladieux, X.G. Zhang, D. Afoufa-Bastien, R.M.V. Sanhueza, M. Sbaghi, B. Le Cam, On the origin and spread of the scab disease of apple: out of central Asia, Plos One 3 (2008) 
Version définitive du manuscrit publiée dans / Final version of the manuscript published in :

Comptes Rendus Biologies (2011), Vol. 334, No.3, p. 237-246, DOI: 10.1016/j=crvi.2010.12.008

\section{Journal homepage: www.sciencedirect.com}

[72] L.V. Kaster, M.E. Gray, European corn borers and western corn rootworms: old and new invasive maize pests challenge farmers on European and North American continents, Maydica 50 (2005) 235-245.

[73] K.S. Kim, M.J. Bagley, B.S. Coates, R.L. Hellmich, T.W. Sappington, Spatial and temporal genetic analyses show high gene flow among European corn borer (Lepidoptera: Crambidae) populations across the central US corn belt, Environ. Entomol. 38 (2009) 1312-1323.

[74] N. Puillandre, S. Dupas, O. Dangles, J.L. Zeddam, C. Capdevielle-Dulac, K. Barbin, M. Torres- Leguizamon, J.F. Silvain, Genetic bottleneck in invasive species: the potato tuber moth adds to the list, Biol. Invasions 10 (2008) 319-333.

[75] M.A. Beaumont, W.Y. Zhang, D.J. Balding, Approximate Bayesian computation in population genetics, Genetics 162 (2002) 2025-2035.

[76] W. Sappington, B.D. Siegfried, T. Guillemaud, Coordinated Diabrotica genetics research: accelerating progress on an urgent insect pest problem, American Entomologist 52 (2006) 92-99.

[77] C.R. Edwards, J. Kiss, New WCR 2006 General spread map for Europe, IWGO Newsletter 28 (2007) 3. 